\title{
A filosofia da ciência de Heidegger
}

\section{Heidegger's Philosophy of Science}

DOI: http://dx.doi.org/10.12957/ek.2014.15182

Joseph Rouse

jrouse@wesleyan.edu tradução Laura M. do Nascimento

lauranasciment@gmail.com

A filosofia da ciência usualmente não é considerada central na obra de Heidegger, ao menos entre os filósofos de língua inglesa, e tampouco se considera que ele tenha contribuído significativamente para a filosofia da ciência. Esta dissociação é evidente em trabalhos recentes: diversos volumes abrangentes sobre a filosofia de Heidegger (p.ex. DREYFUS e HALL, 1992; GUIGNON, 1993) não incluem nenhum ensaio sobre sua filosofia da ciência, ao mesmo tempo em que as concepções de Heidegger quase nunca são consideradas pelos filósofos da ciência anglófonos. No entanto, a rejeição do envolvimento de Heidegger com a filosofia da ciência está equivocada em ambos os sentidos.

Compreender a filosofia da ciência de Heidegger exige que seu projeto seja situado em relação ao giro epistemológico central ao neo-kantianismo e à fenomenologia husserliana, ainda dominantes na filosofia. Para ambos os neo-Kantianos (incluindo os positivistas lógicos) e Husserl, a reflexão filosófica sobre a ciência diz respeito ao conhecimento científico. A ciência visava estabelecer conhecimento objetivamente válido, enquanto a filosofia buscava clarificar as bases de sua validade. Inicialmente, pode parecer óbvio que a evidência observacional é a base do conhecimento empírico. No entanto, não era tão óbvio como a evidência empírica estava relacionada aos juízos ou aos enunciados científicos sobre o mundo de maneira a garantir a sua validade objetiva.

O desafio de explicar a validade científica ou a objetividade era complexo. Primeiro, ter-se-ia que compreender como as afirmações científicas eram significativas, ou seja, como os enunciados ou juízos descreviam o mundo de certa maneira ao invés de outra. Segundo, ter-se-ia que compreender como a evidência empírica poderia tanto justificar ou desafiar tais representações. Além disso, havia obstáculos duplos para que cada desafio pudesse ser satisfeito. Não era suficiente estabelecer uma relação motivacional contingente ou causal entre fazer uma afirmação e ou ter uma experiência ou aceitar outras afirmações. Afirmações válidas expressam o que qualquer conhecedor racional deve dizer, com base na relação evocada como fundamento. Os fundamen-

\footnotetext{
*Nota dos editores: Texto publicado originalmente em: A Companion to Heidegger, Hubert Dreyfus and Mark Wrathall (eds.), Blackwell, 2005, pp. 173-189. O corpo editorial da revista Ekstasis agradece a gentil e pronta resposta do autor e seu primeiro contato com a editora a fim de tratar do processo de solicitação de direitos autorais para a publicação dessa tradução, assim como o esforço da tradutora em viabilizar financeiramente a publicação, por meio da solicitação de verba junto à Unicamp para os custeio das taxas de direitos autorais e de publicação.

** Laura Machado do Nascimento é doutoranda do Programa de Pós-graduação em Filosofia da Universidade Estadual de Campinas. Esta tradução foi realizada com o apoio do prof. Dr. Róbson Ramos dos Reis (UFSM) e do prof. Dr. Marco Ruffino (UNICAMP), aos quais agradece, e da Fundação de Apoio à Pesquisa do Estado de São Paulo (FAPESP), pelo projeto 2014/03029-2.
} 
tos para o significado e a justificação das afirmações científicas, assim, devem ser normativos, mais do que meramente empiricamente contingentes, e a sua fundamentação deve ser intersubjetiva.

Ainda que ignorando diferenças importantes em outros aspectos, podemos identificar duas características comuns às respostas husserliana e neo-kantiana a esses desafios. Primeiro, os fundamentos fornecidos para o significado e a validade do conhecimento científico eram estruturas ou relações racional ou transcendentalmente necessárias. Segundo, o domínio destas estruturas ou relações necessárias era independente das contingências do mundo no qual nos encontramos. Não são os meros fatos sobre esse mundo que determinam o que nós devemos fazer ou pensar. Por isso, ao procurar fundamentos para normas epistêmicas, esses filósofos confiavam suas reflexões aos domínios "extramundanos" da lógica pura ou da consciência transcendental. A lógica não era uma ciência empírica de como as pessoas realmente raciocinam, mas um estudo de estruturas formais ou normas que o pensamento real pode não satisfazer. A consciência transcendental husserliana era, de maneira similar, não um domínio psicofísico contingente examinado empiricamente, mas um domínio de significados puros que se tornam acessíveis somente quando a preocupação com a existência mundana é temporariamente suspensa. Em cada caso, as afirmações reais feitas nas ciências em sequência aos eventos empíricos contingentes eram tomadas como sendo significativas e justificadas porque elas instanciavam (imperfeitamente) estruturas ideais de necessidade racional ou eidética.

Heidegger objetou fundamentalmente esse tipo de afastamento do mundo histórico e concreto nos quais os agentes humanos estão situados. Ao localizar a normatividade da atividade e da compreensão humanas em necessidades ideais da lógica pura ou da consciência transcendental, Husserl e os neo-kantianos desconectaram a reflexão filosófica da nossa real situação mundana. Ainda poderia haver uma base intermediária entre apelos a estruturas necessárias e uma filosofia da visão de mundo (Weltanschauung) circunscrita por uma situação cultural e histórica particular, de maneira a abandonar qualquer aspiração a uma compreensão filosófica mais ampla? A resposta de Heidegger a este dilema desafiou as pressuposições mais básicas que levaram os neo-kantianos e Husserl em direção a uma concepção epistemológica de ciência.

Epistemólogos tratam o conhecimento como uma relação entre entes: um conhecedor, um objeto conhecido e a representação do conhecedor sobre o conhecido. A tarefa é, então, compreender como estes entes devem estar relacionados para atingir conhecimento genuíno. Heidegger pensava que pressuposi- 
ções errôneas e não-examinadas subjazem quaisquer concepções desse tipo, de conhecedores como um tipo especial de ente (uma mente, consciência, falante da linguagem ou agente racional), e de conhecimento como uma relação entre entes, insistindo que "a esse ente não se deve aplicar dogmática e construtivamente nenhuma ideia de ser e de realidade efetiva, por mais 'evidente' que ela seja." (SZ: 16[MR]) ${ }^{1}$. Ao colocar a questão do ser (do que significa ser, ou da inteligibilidade dos entes enquanto entes), Heidegger buscou superar pressuposições não-examinadas sobre conhecimento ou consciência, e engajar-se em um questionamento filosófico mais radical. Recorrendo à filosofia grega e medieval, ele falou do "ser" de um ente como uma maneira de considerar sua inteligibilidade como o ente que é. Ao assumir esse termo, Heidegger buscou evitar presumir que a inteligibilidade ("ser") dos entes é ela mesma um ente (um significado, uma aparência, um conceito ou um pensamento).

A tentativa de Heidegger de evitar reificar relações entre conhecedor e conhecido ao evitar pressuposições epistemológicas também o levou a reconceber a compreensão humana. A maioria dos filósofos considera que estados mentais ou atitudes proposicionais (perceber, julgar, desejar) são nossa maneira básica de nos relacionar e compreender as coisas. Heidegger falou de maneira mais abrangente de nossas várias ocupações ou comportamentos com respeito aos entes, e desafiou a pressuposição de que tais comportamentos sempre envolvem, ao menos implicitamente, representações mentais ou linguísticas (Heidegger referiu-se aos "nossos" comportamentos como "Dasein", um termo que denota nossa maneira distintiva de ser). No comportamento cotidiano, nós compreendemos os entes que encontramos, mas Heidegger interpretou a compreensão como sendo uma competência prática ao invés de uma cognição ou representação mental (SZ: 143). Cognição e conhecimento são supostamente derivativos de ("fundados em") tais compreensões práticas cotidianas.

Uma tese central em Ser e Tempo é a de que qualquer compreensão de entes pressupõe uma compreensão do ser. Essa afirmação aparentemente obscura é clarificada pelo paralelo de Haugeland (1988) com o xadrez. Não podemos ter um encontro com uma torre sem alguma forma de compreensão do jogo de xadrez. Nos termos de Heidegger, a "descoberta" dos entes do xadrez (peças, posições, movimentos ou situações) pressupõe uma "abertura" prévia do xadrez como o contexto para que eles façam sentido. O "ser" das torres ou dos

1 Nota de tradução: As traduções das citações de Ser e Tempo são retiradas da versão em português de Fausto Castilho, publicada pela Editora Vozes/Unicamp em 2012. Por vezes, as citações foram alteradas pela revisão do Prof. Dr. Róbson dos Reis, nestes casos, indicou-se a alteração com a sigla MR - modificado pelo revisor. 
garfos do cavalo ${ }^{2}$ é o seu lugar no interior do jogo, atribuindo sua inteligibilidade enquanto os entes que são. O próprio jogo somente faz sentido, contudo, como uma maneira possível de nos comportarmos. Em quaisquer comportamentos em direção a entes, então, o que compreendemos mais fundamentalmente é o mundo enquanto uma configuração significativa de maneiras possíveis para que o Dasein seja, e nosso próprio direcionamento a essas possibilidades: "Aquilo que se pode no compreender como existencial [uma estrutura essencial de nossa maneira de ser] não é um quê, mas o ser como existir. O ser-aí não é um ente subsistente que possui, além disso, como acréscimo o poder algo, mas ele é primariamente ser-possível." (SZ: 143, ST: 407-9 [MR]). A dificuldade de compreensão aqui é a afirmação de Heidegger de que o "mundo" (a situação ou o contexto) cuja abertura permite a descoberta de entes não é em si mesmo um ente ou uma coleção de entes. Se perguntarmos o que há, não há nada exceto os variados e diversos entes que podemos descobrir. Mas podemos descobri-los somente porque compreendemos o ser e, desse modo, pertencemos a uma situação histórica específica ou "mundo", uma configuração significativa de modos possíveis de ser para nós. Contudo, as palavras "possível" ou "possibilidade" podem ser enganosas. Heidegger não se referia a realidades possíveis (objetos definidos, propriedades, e relações que poderiam ser obtidas, mas que na verdade não são), mas a possibilidades reais (uma orientação em direção a modos de ser definidos, mas não completamente determinados). Podemos nos comportar em direção a possibilidades sem representá-las como tais, mesmo implicitamente.

Agora, podemos perguntar como Heidegger (em Ser e Tempo) concebeu a ciência e sua relação com a filosofia. A filosofia da ciência inicial de Heidegger tinha três temas principais: a prioridade da ontologia fundamental para a ciência, a necessidade de uma "concepção existencial de ciência", e a significatividade ontológica da ciência enquanto descoberta do subsistente (Vorhanden).

A compreensão de Heidegger da filosofia como ontologia fundamental contrasta-se nitidamente com as concepções lógicas e epistemológicas tradicionais da contribuição da filosofia para a ciência. As últimas, ele pensou, "ficam para trás, investigando o estado ocasional de uma ciência" até agora (SZ: 10 [MR]). Tais abordagens negam a orientação para o futuro da pesquisa científica e, assim, equivocam-se completamente quanto ao que importa na ciência. Heidegger pensava que 'O autêntico 'movimento' de uma ciência reflete-se na revisão mais ou menos radical (mesmo que não transparente por si mesma) dos concei-

2 Nota de tradução: No xadrez, um garfo é uma tática em que uma única peça ataca diretamente outras duas ou mais peças de maneira simultânea. 
tos fundamentais. O nível de uma ciência determina-se a partir de o quanto é ela é capaz de uma crise em seus conceitos fundamentais" (SZ: 9[MR]). Uma filosofia da ciência que defina sua tarefa normativa pela orientação já aceita de uma disciplina científica particular visa assegurar o que a própria ciência busca superar. Heidegger pensou que a filosofia, em vez disso, poderia contribuir para "uma lógica produtiva, no sentido em que ela como que salta na frente para dentro de uma região particular de ser, abrindo-a pela primeira vez na sua constituição de ser, fazendo com que as estruturas a que chega estejam disponíveis para as ciências positivas como guias transparentes da interrogação" (SZ: 10[MR]). Heidegger pensou que a filosofia poderia fazer isso porque as ciências, como quaisquer outras atividades humanas, procedem a partir de uma compreensão prévia do ser dos entes com que se defrontam. Tal compreensão envolve uma compreensão prática (não uma descrição articulada) de quais entes estão envolvidos, como abordá-los de um modo revelador, e o que resultaria em sucesso ao lidar com eles. A descoberta e a articulação do que há em um domínio científico particular baseia-se em, e posteriormente desenvolve, essa abertura prévia do ser. A reflexão filosófica sobre a compreensão do ser de uma ciência particular (sua ontologia "regional") considera as condições a priori da possibilidade de investigar entes em seu domínio (SZ: 11), mas ela não procura, assim, conhecimento a priori. Heidegger afirmou que "o sentido original do a priori" não tinha nenhuma relação com o conhecimento (GA 20: 34). Em vez disso, ele utilizou o termo "a priori" para designar o que é ontologicamente prévio, as condições de possibilidade dos próprios entes (enquanto o tipo de ente que são), mais do que as condições de possibilidade do nosso conhecimento sobre entes. O convite de Heidegger para a reflexão sobre as condições a priori da possibilidade dos entes, assim, se opõe diretamente a qualquer filosofia de poltrona [armchair philosophy] que busque o conhecimento a priori. Heidegger, em vez disso, observou aprovadamente que muitas disciplinas científicas contemporâneas (especificamente a matemática, a física, a biologia, as ciências históricas e a teologia) estavam engajadas em reflexões renovadas sobre seus fundamentos conceituais, e que tais desenvolvimentos eram giros apropriadamente filosóficos no interior dessas disciplinas (SZ: 9-10). A ontologia filosófica deveria ser contínua com tais desenvolvimentos científicos. Seus modelos explícitos para a ontologia filosófica foram as contribuições de Platão, Aristóteles e Kant. No caso do último, ele pensou, "o resultado positivo da Crítica da Razão Pura de Kant não consiste numa 'teoria' do conhecimento, mas na tentativa de pôr em relevo o que pertence à natureza em geral" (SZ: 10-11; ST: 55). A obra de Kant não era "prévia" a de Newton, mas um comprometimento filosófico (ontológico) com a física newtoniana. 
A filosofia poderia contribuir distintivamente para a reflexão ontológica no interior de qualquer ciência particular, por duas razões. A razão mais importante era a de que a abertura "regional" do ser no interior de qualquer domínio científico particular era supostamente dependente da compreensão do ser em geral. Assim como compreender as torres exige compreender o xadrez, e o xadrez é compreendido como um modo possível do ser-no-mundo do Dasein, Heidegger pensava que a abertura do ser dos entes no interior de qualquer domínio científico pressupõe uma compreensão do ser em geral. Até que a compreensão do ser tivesse sido esclarecida, qualquer ontologia regional, "não importando o quão rica e firmemente ajustada é o sistema de categorias que tem à sua disposição, permanece cega e desvirtuada de seu objetivo mais próprio" (SZ: 11).

A segunda razão por que o Heidegger inicial via a reflexão filosófica como essencial para a ciência volta-se para sua concepção "existencial" de ciência. Heidegger pensava que se precisava de uma concepção "existencial” de ciência porque "as ciências têm, como comportamentos humanos, o modo de ser desse ente (homem)" (SZ: 11; ST: 59). O modo de ser do Dasein é orientado-para-o-futuro; ele "avança em direção a [suas] possibilidades", e o faz por preocupação com seu próprio ser. A relação mais básica do Dasein consigo mesmo não é a auto-consciência, mas o cuidado: o Dasein é "o ente cujo próprio ser está em jogo" (SZ: 42[MR]), de maneira que qualquer coisa que ele faça, responde a essa questão. Note que, para Heidegger, termos como "cuidado", "preocupação" ou "solicitude" não se referem a estados mentais, mas a modos totais do comportamento de alguém. Contudo, uma concepção existencial de ciência não enfatizaria o comportamento público em detrimento de estados mentais privados; Heidegger buscou evitar distinções familiares entre "interior" e "exterior" ou domínios público e privado. O contraste relevante era temporal: uma concepção existencial de ciência enfatizava possibilidades científicas, em contraste com “a concepção 'lógica' que compreende a ciência a partir de seus resultados e a determina como uma conexão justificacional de proposições verdadeiras, ou seja, válidas" (SZ: 357[MR]). Heidegger, assim, focou na ciência como algo que as pessoas fazem, mais do que no conhecimento científico enquanto adquirido e avaliado retrospectivamente. Compreendida existencialmente, a ciência não é a acumulação de conhecimento estabelecido, mas está sempre voltada em direção a possibilidades das quais ela ainda pode não compreender ou articular totalmente.

Heidegger concedeu prioridade filosófica a sua concepção existencial-ontológica da ciência, mas também pensou que a maior familiaridade entre concepções lógicas e ônticas mostrava algo importante sobre a ciência. Embora a ciência 
sempre pressuponha uma compreensão do ser, o projeto científico de descobrimento do que e como são os entes em seu domínio obscurece a compreensão do ser que torna a investigação possível. Seu foco determinado sobre os entes que investiga toma como certa a compreensão do ser que provê seu foco. Agora, podemos compreender a segunda razão por que Heidegger pensou que a filosofia era indispensável à ciência, como um desafio a uma tendência "normalizante" inerente à própria pesquisa científica (HAUGELAND 1998: cap. 13; 2000). A descrição de Thomas Kuhn (1970) da ciência normal expressa eloquentemente aquela tendência no trabalho científico que Heidegger considerou como inevitavelmente dependente de questionamentos filosóficos (não importando se são cientistas ou filósofos que levantam essas questões). Para Kuhn, assim como para Heidegger, a ciência "normal" evita a controvérsia sobre os fundamentos a fim de desenvolver em maiores detalhe e precisão sua compreensão prática e conceitualmente inquestionada de um domínio de entes. Quando deixada a sua própria sorte, ambos pensaram, as ciências suprimem qualquer questionamento fundamental de como seus domínios constituem campos de investigação possível. Quando esse tipo de questionamento torna-se inevitável por meio do colapso da pesquisa positiva em um domínio particular, os cientistas não empreendem a investigação ontológica pelos seus benefícios próprios, mas buscam apenas reconstituir suas capacidades de prestar atenção aos entes sem ter que investigar o seu ser. Kuhn e Heidegger divergiram sobre a aceitação do fechamento da investigação ontológica, Kuhn aceitou-a, enquanto Heidegger não o fez.

Heidegger via a normalização científica como uma dimensão ontológica essencial da ciência, mais do que uma tendência psicológica ou pressão social contingente e possivelmente objetável. Aqui emerge o tema final na filosofia da ciência inicial de Heidegger, a conexão entre ciência e a "subsistência" (Vorhandenheit) como um modo de ser. Embora Heidegger tenha insistido mesmo em Ser e Tempo que o ser não era ele mesmo um ente, ainda poderia haver uma ciência do ser (ontologia fundamental), porque havia distinções articuláveis na compreensão do ser. Essas distinções "fundamentais" não definiam as regiões ontológicas que demarcam os domínios de entes estudados pelas ciências positivas (natureza, matemática, linguagem, história e afins), ao invés, marcavam diferentes modos de ser, da inteligibilidade enquanto entes. Mais basicamente, Heidegger distinguiu o ser do Dasein (ser-no-mundo) de modos de ser "intramundanos". Ele nem sempre foi cuidadoso em distinguir a nós, os entes cujo modo de ser é o ser-aí, do próprio ser-aí como um modo de inteligibilidade, mas a distinção é crucial. Heidegger buscou compreender o ser, não fazer antropologia empírica. 
Heidegger inicialmente distinguiu o modo de ser do ser-aí da "subsistência" das coisas (tais como mente, alma, ego, corpo ou pessoa). Ele então argumentou, contudo, que os entes com os quais nós lidamos nas nossas vidas cotidianas ordinárias tampouco são subsistentes. Ferramentas não são um conjunto de entes com propriedades intrínsecas. Algo só pode ser um martelo, em seu conhecido exemplo, em "relação" a pregos, tábuas, carpintaria e, em última instância, aquelas atividades humanas para as quais martelar e cingir são integrantes. Essas interrelações são mais básicas ontologicamente do que aquilo que está relacionado: “A rigor, um utensílio nunca 'é'... Estas coisas' [relacionadas a ferramentas] nunca se mostram de imediato separadas, para preencher um quarto como soma de coisas reais. $\mathrm{O}$ que encontramos como mais próximo de nós, embora atematicamente, é o quarto" (SZ: 68[MR]). Além disso, ferramentas funcionam melhor quando não precisamos pensar sobre elas de nenhuma maneira, e podemos focar na tarefa em questão (o que está diante de nós). O ser da ferramenta não é a subsistência de um ente com propriedades, mas a disponibilidade de uma tal funcionalidade normalmente tácita.

Contudo, um tipo de ferramenta realmente chama atenção para si mesmo. Signos somente funcionam quando nós lhes reparamos. Signos ainda têm o ser da ferramenta, significando somente no interior de um contexto prático mais amplo. Asserções, no entanto, são signos que permitem às coisas mostrarem-se diferentemente. Asserções indicam entes e os tornam comunicáveis. Heidegger pensou que a asserção é, com esse respeito, dependente do envolvimento prático cotidiano. Falar das coisas como subsistentes pressupõe uma compreensão prática do "mundo" aparelhadamente interconectado.

A significância ontológica da ciência para o Heidegger inicial estava ligada à asserção linguística como um modo derivativo de interpretação. Nesse sentido, a filosofia da ciência inicial de Heidegger permaneceu bastante tradicional. A ciência descreve entes e, portanto, os priva da significância humana ordinária. Algumas asserções realmente posicionam os entes em uma situação prática e local. Na ciência, no entanto, descobrimos entes despidos de seus envolvimentos práticos, como meramente subsistentes. Então falamos sobre um martelo não como apropriado e disponível para a tarefa a ser realizada, mas como um objeto com massa e localização espaço-temporal. Ele, desse modo, adquire um novo modo de inteligibilidade. Seus envolvimentos contextuais e locais são substituídos por uma contextualização teórica: 
O que é decisivo para o surgimento [da física matemática] ... está no projeto matemático da própria natureza. Este projeto descobre previamente algo constantemente subsistente (matéria), e abre o horizonte para que o olhar condutor considere seus momentos constitutivos quantitativamente determináveis (movimento, força, localização, e tempo). (SZ: 362[MR])

Contudo, ao falar sobre a projeção "matemática", Heidegger enfatizava a determinação ontológica primária de entes das ciências, não o seu caráter parcialmente quantitativo: "Ta mathémata significa em grego aquilo que o homem já sabe de antemão ao considerar os entes e ao lidar com as coisas: nos corpos, é o corpóreo, nas plantas, é o botânico, nos animais, é o zoológico e no homem, é a humanidade (das Menschenartige)". (GA 5: 78). Essa compreensão ontológica da interpretação teórica cumpriu dois papéis. A abertura e a articulação teórica dos entes como subsistentes foi um feito genuíno e verdadeiro da ciência empírica. Esse feito, no entanto, foi duplamente dependente da sua clarificação por meio da ontologia filosófica.

Na sua dependência mais óbvia, ciência e cognição, de modo geral, são modos derivativos de compreensão. Asserções sobre entes subsistentes são inteligíveis somente por meio da imersão primária do ser-aí em um mundo. A ontologia fundamental, então, clarifica a relação entre asserções na ciência teórica e a compreensão do ser que elas pressupõem, por exemplo, ao mostrar como a descoberta teórica de entes subsistentes surgiu pela modificação do envolvimento cotidiano com as ferramentas disponíveis (SZ: 69b). Mas a asserção científica também era supostamente derivativa de uma maneira mais problemática. Asserções podem "indicar" corretamente entes como subsistentes. Mas as asserções também, assim, permitem indispensavelmente o-que-é-dito (das Geredete) passar por "falatório" (Gerede) que obscurece a compreensão. Asserções são "ambíguas" porque elas podem ser enunciadas com ou sem compreensão e, mais importante, com ou sem responsabilidade sobre o que está sendo falado. Ao tornar a compreensão comunicável, a asserção também torna possível a mera aparência com a compreensão.

Compreender por que Heidegger pensou que as asserções científicas inevitavelmente nos afastam da compreensão genuína exige uma maior consideração do tratamento de Heidegger da asserção e do significado. A maioria dos seus contemporâneos filosóficos, impressionados pela necessidade de compreender o erro e o pensamento sobre coisas não-existentes, postularam significados 
como intermediários entre pensamento e coisas. Podemos falar e pensar sobre o que não existe, ou falsidades sobre o que existe, porque nossa compreensão dos significados é mais básica do que nosso conhecimento das coisas. Heidegger rejeitou tais apelos a intermediários semânticos. Asserções "indicam" os entes mesmos, não os significados: "O enunciado ['o quadro na parede está pendurada de maneira torta' ' ... em seu sentido mais próprio refere-se ao quadro real na parede. Somente isto e não e outra coisa é o visado" (SZ: 217[MR]). Como os atuais defensores de teorias causais da referência, Heidegger explica a articulação linguística situando a fala no interior de um padrão mais amplo de interação, em vez de uma estrutura linguística ou teórica. $\mathrm{O}$ erro é uma relação holística com os entes com os quais interagimos discursivamente, não uma compreensão direta dos significados que falham em representar qualquer coisa corretamente. Heidegger diferiu dos atuais defensores de uma teoria causal da referência por considerar nossas condutas com o ambiente como sendo prático-normativas, ao invés de causais. Eles fazem um esforço comum, no entanto, em construir a linguagem como interação com o mundo, ao invés de uma estrutura formal de significados conectada ao mundo somente indiretamente.

Para Heidegger, no entanto, a afirmação de que a asserção é um comportamento em direção a entes dá uma significância elevada e irônica à possibilidade de repetição do que é asserido. Ao tornar o-que-é-dito comunicável, asserções podem tornar-se distantes dos entes que indicam e os quais descrevem. Seus fundamentos imediatos tornam-se, então, não os próprios entes, mas outras asserções. Existem duas maneiras distintas nas quais o "falatório" substitui os entes sobre os quais se fala por outras asserções como o primariamente compreendido. Mais obviamente, asserções podem estar fundadas em testemunho: eu posso fazer uma asserção não a partir da minha própria maneira de compreender como as coisas estão, mas meramente a partir do que outros dizem, com a autoridade anônima do que "alguém" diz. Mas as asserções podem também estar fundadas inferencialmente sobre outras asserções, com sua autoridade mediada por redes complexas de outras afirmações. Essas duas formas de interdependência são entrelaçadas, pois desenvolver e sustentar redes complexas de crenças exige compartilhar e transmitir o que outros dizem.

A indispensabilidade de redes inferenciais para a compreensão científica ressalta a insistência de Heidegger de que sua descrição do "falatório" não é completamente depreciativa. Ele não rejeitou a compreensão teórica articulada, somente reconheceu que, ao desenvolver mais extensivamente as redes teóricas articuladas, as ciências se arriscam a tornar-se mais envolvidas em seus vocabulários e teorias próprios do que nas coisas a serem compreendidas. 
Contrariamente à imagem falibilista familiar das ciências, Heidegger preocupou-se com o fato de que o desenvolvimento de uma ciência feche a possibilidade de que entes possam resistir a nossas maneiras familiares de encontrá-los e falar sobre eles. Para Heidegger, a ciência precisa da filosofia a fim de permanecer "na verdade". O maior perigo da ciência não é o erro, que é mais prontamente corrigido por investigações ulteriores, mas o vazio de asserções fechadas para a descrição genuína de entes (sobre isso, a preocupação de Heidegger apresenta afinidades surpreendentes com McDowell, 1994). Assim, Heidegger insistiu que a verdade enquanto asserção correta estava fundada em um sentido mais fundamental de verdade como "descobrimento" [unhiddenness]: a correção por si só não garantiria a compreensão genuína a não ser que os entes eles mesmos fossem continuamente salvos do sepultamento na conversa rasa. Podemos então conectar a descrição de Heidegger das ciências como a descoberta dos entes enquanto subsistentes, e sua insistência na necessidade de fundar a ciência na ontologia fundamental. Ao focar na descoberta cognitiva do subsistente, a ciência inevitavelmente nos afasta da sua possibilidade "mais alta", a prontidão e a abertura para a crise nos seus conceitos básicos por causa da fidelidade aos entes em questão. Somente no afastamento "filosófico" do envolvimento com o falatório sobre entes, em direção à compreensão do ser no interior da qual os entes são descobertos, a ciência poderia permanecer aberta à verdadeira abertura das coisas mesmas.

A tendência inerente à ciência de obscurecer com um véu de falatório os entes que descobre é repetida e reforçada pela concepção epistemológica dominante de reflexão filosófica. As ciências, nos seus próprios esforços de descobrir e descrever entes, perdem de vista os entes mesmos por meio do envolvimento em uma rede de asserções inferencialmente conectadas. Filósofos de orientação epistemológica tornam essa tendência de "inclinação" para longe da compreensão dos entes mesmos, explícita e deliberada. Enquanto a ciência busca compreender o mundo, epistemólogos consideram a cognição científica como o seu próprio objeto de estudo, a um passo da preocupação científica. Para Heidegger, por contraste, a tarefa filosófica mais importante no que diz respeito às ciências era ajudar a renovar a sua abertura verdadeira às "coisas mesmas". Nesse respeito, o questionamento do ser de Heidegger seria seriamente mal compreendido se fosse considerado como um afastamento da ciência em direção a algo obscuro e "metafísico". Ao pensar sobre o ser dos entes descobertos pela ciência, não pensamos sobre alguma outra coisa. Ser não é ele mesmo um ente, mas somente a abertura dos entes enquanto inteligíveis. A reflexão ontológica de Heidegger não se afastaria do objeto de estudo das ciências, mas, ao invés disso, buscaria um novo retorno às "coisas mesmas" em 
sua abertura essencial. Para Heidegger, as reflexões sustentadas por Aristóteles sobre a biologia ou as de Kant sobre a mecânica não foram um fracasso em distinguir claramente a filosofia da ciência mas, em vez disso, reconheceram a vocação mais alta da filosofia. Aqui, como em outros lugares, o trabalho de Heidegger tem afinidades importantes com o naturalismo filosófico da segunda metade do século XX (ROUSE, 2002).

Não obstante, havia tensões no interior da filosofia da ciência inicial de Heidegger, indicando dificuldades fundamentais em seu projeto como um todo. A ontologia fundamental era uma investigação transcendental-filosófica a-histórica sobre a existência humana enquanto essencialmente histórica e mundana. Nas suas viradas para as estruturas formais da lógica pura ou da consciência transcendental, Heidegger pensou que seus oponentes filosóficos haviam danificado a conexão com o mundo dos fenômenos que buscavam entender. Heidegger opôs-se inflexivelmente a qualquer formalização comparável de suas próprias categorias ontológicas. O a-fim-de-em-função-das-relações [in-order-to-for-the-sake-of-relations] que articula o ser do que é disponível (Zuhanden) pode, ele admitiu,

ser formalmente apreendido no sentido de um sistema de relações. Mas ... tais formalizações nivelam de modo tão amplo os fenômenos que o conteúdo fenomênico próprio pode se perder. ... O "para algo" [in-order-to], o "em-função-de" [for-the-sake-of], o "com-qual" [with-which] ... são, ao invés disso, relações nas quais o ver circunspecto ocupado como tal se detém em todo momento. (SZ: 88 [MR])

Não estava claro, no entanto, por que as estruturas essenciais da ontologia fundamental também não se dissiparam em relações imateriais e a-históricas (BRANDOM, 2005 apresenta uma explicação lúcida de como uma tal formalização da disponibilidade poderia ser). Heidegger buscou mostrar como essas estruturas eram manifestas nos comportamentos concretos do Dasein enquanto ser-no-mundo, mas em vários pontos, surgiram questões sobre como as estruturas ontológicas conectam-se aos comportamentos concretos e aos entes. Por exemplo, como as práticas cotidianas de teorização científica (concebidas "existencialmente") do Dasein-científico relacionam-se com a categoria ontológica abstrata da ciência enquanto uma descoberta teórica do subsistente? De maneira 
mais geral, como as diferenças entre os modos de ser (Dasein, disponibilidade ou subsistência) eram relevantes para a determinação ontológica de domínios científicos como a natureza ou a história? Como e por que, por exemplo, as investigações das ciências humanas sobre os seres humanos devem ser determinadas pela nossa compreensão do Dasein enquanto nosso modo de ser? Da mesma maneira, qual é a relação entre nós, enquanto casos do Dasein, e nós enquanto entes físicos ou biológicos? Finalmente, a descrição de Heidegger da ciência incorporou uma "passagem" ontologicamente decisiva, mas difícil de identificar concretamente, da "compreensão do ser que conduz o trato ocupacional com o ente intramundano" para o "ver o ente disponível que vem ao encontro de uma 'nova' maneira, como subsistente" (SZ: 361[MR]). Essa passagem envolve tanto uma mudança da comunicação contextual (martelos são "muito pesados" ou "inapropriados") para asserções temáticas sobre massa e localização no espaço-tempo enquanto propriedades subsistentes, quanto da compreensão cotidiana para a "projeção matemática da natureza". Contudo, Heidegger meramente asseriu tal transformação sem descrevê-la adequadamente. A passagem associada da familiaridade prática com os signos linguísticos enquanto "equipamentos para indicar" para a asserção explícita e descontextualizada era igualmente central e obscura na filosofia da linguagem inicial de Heidegger.

A reflexão sobre a ciência foi central para a reorientação do projeto filosófico de Heidegger em meados dos anos 1930. Notavelmente, Heidegger abandonou a ontologia fundamental. Sua tentativa de articular diferenças essenciais entre modos de ser e, assim, tornar a ontologia "ciência" filosófica, foi suplantada por uma compreensão historicizada da inteligibilidade dos entes: "A metafísica funda uma época, (...) através de uma interpretação específica do ente e de uma acepção específica da verdade." (GA 5: 75) ${ }^{3}$. Não somente o modo de ser do Dasein perde centralidade, como a subsistência e a disponibilidade também deixaram de ser categorias básicas. A ciência, então, não mais teria a significância ontológica de descobrir os entes como subsistentes.

O abandono da ontologia fundamental transformou significativamente a fenomenologia da ciência de Heidegger, desenvolvida mais extensivamente em "A época da imagem de mundo" (GA 5). Tendo perdido sua significância ontológica- fundamental, a ciência seria reconcebida como sendo um fenômeno essencial da modernidade. A descrição anterior de Heidegger da ciência enquanto a descoberta do subsistente agora parecia reminiscente demais das con-

3 Nota de tradução: As traduções do texto "A época da imagem de mundo" de Heidegger foram retiradas da versão em português feita pela Profa Dra Cláudia Drucker ainda não publicada, com a devida permissão da tradutora, pela qual agradecemos. 
cepções tradicionais da ciência enquanto cognição ou asserção justificada. Para substituir esse resíduo da epistemologia tradicional, Heidegger caracterizou a ciência moderna, em vez disso, como pesquisa. A pesquisa científica envolve seus praticantes em "o âmbito em que assume a configuração essencial do homem técnico, de modo essencial. Só deste modo ele se torna eficaz e, no sentido da sua época, efetivo.” (GA 5: 85). A ciência moderna, assim, não suspende a preocupação prática com os entes, mas a intensifica.

Heidegger reteve a afirmação de Ser e Tempo de que "a projeção matemática da natureza" foi decisiva para a ciência moderna, mas mudou radicalmente sua concepção do que essa projeção alcançou. Previamente, o caráter "matemático" da física libertava entes de seus envolvimentos práticos para tematizá-los enquanto objetos. Ao invés disso, em sua visão revisada, a projeção matemática dos entes físicos intensifica e governa mais rigorosamente as condutas dos cientistas com elas:

... cada procedimento exige de saída uma esfera dentro do qual se move. Mas o procedimento básico da pesquisa consiste precisamente em franquear tal esfera. Ele se consuma através da projeção de um traço fundamental [Grundriss] de algum âmbito do ente: por exemplo, quando, na natureza, um traço básico dos processos naturais é projetado. O projeto delineia de que modo o procedimento cognitivo adere, obrigatoriamente, à esfera franqueada. Esta obrigatoriedade é o rigor da pesquisa (...) Esta projeção da natureza se certifica dela, à medida que a pesquisa física junge a si cada passo investigativo. (GA 5: 77, 79)

Heidegger apresentou tal movimento para adiante rigorosamente auto-vinculante no interior de um domínio projetado de entes como a característica essencial e primeira da ciência que foi transformada em pesquisa.

Uma segunda característica distintiva da pesquisa é ser guiada por um modo distintivo de proceder. Ao avançar mais em um domínio projetado, a pesquisa deve estar aberta à variação e à novidade em meio aos fenômenos descobertos, ainda que necessite sustentar a generalidade e a objetividade de sua concepção global. Esta demanda dupla explica a centralidade das leis da natureza na explicação científica moderna. 
A abundância do particular, isto é, dos fatos, só se mostra dentro do âmbito de visão do caráter de sempre-outro da mudança. O procedimento deve, por isso, representar o mutante em sua mutabilidade, torná-lo fixo, ao mesmo tempo em que concede ao movimento a sua mobilidade. A regra é aquilo que, nos fatos, permanece, e o que enquanto tal é constante nas suas modificações. A lei é aquilo que é constante nas modificações junto com a necessidade do seu desenrolar. Os fatos se tornam os fatos que são, pela primeira vez, ao adentrar o âmbito de visão da regra e da lei. A pesquisa factual no domínio da natureza é, em si, a instalação e comprovação da regra e da lei. (GA 5: 80)

Esse processo de unificar fenômenos múltiplos sob leis mais gerais simultaneamente estende e legitima a projeção da natureza que governa a pesquisa em andamento. "...tem a característica do esclarecimento a partir do claro, da explicação. Esta permanece ambígua. Ela fundamenta um desconhecido através de um conhecido e, ao mesmo tempo, certifica-se deste através de um desconhecido." (GA 5: 80). Os fatos recebem sua determinação definitiva por meio da subsunção a uma lei, cuja autoridade é garantida pelo sucesso em explicar uma aglomeração de fatos.

Heidegger apresentou a virada à ciência experimental como uma consequência de sua nova maneira de proceder ao invés de sua base. Somente com a reconcepção da natureza como uma unificação de diversos eventos sob uma lei, a criação de novos fenômenos em laboratório poderia ser pensada como produzindo insights fundamentais mais do que simplesmente uma proliferação de curiosidades. “... o que é decisivo no experimento: começar com uma lei, que é tomada por base. Preparar e estabelecer um experimento significa representar uma condição de acordo com a qual um sistema específico de movimentos pode ser acompanhado na necessidade do seu decurso, de tal forma que o sistema pode ser dominado de antemão pela calculação." (GA 5: 81). Essa mudança é um imperativo geral da pesquisa, no entanto, e não meramente a projeção da natureza como um domínio distintivamente governado por leis. Para Heidegger, todos os métodos de pesquisa modernos, da experimentação à crítica de fontes históricas, dependeram de um jogo comparável a um esquema explanatório e os objetos particulares ou eventos subsumidos nele. A pesquisa inevitavelmente cria disciplinas especializadas, cada uma buscando um esquema explanatório característico tão avançado quanto possível. 
Para Heidegger, essa extensão inexorável dos frameworks explanatórios é uma terceira característica fundamental da ciência moderna, enquanto empreendimento (Betrieb, a tradução inglesa padrão de "Betrieb" como "atividade em andamento" e "atividade contínua" perde o sentido de empreendimento de negócios e trabalho industrial). O que conduz a pesquisa científica não é a significância dos resultados buscados, mas a necessidade de garantir e expandir o empreendimento da própria ciência:

$\mathrm{O}$ procedimento que conquista as esferas individuais de objetos não se limita a acumular resultados. É bem antes o caso que ele se prepara para um novo procedimento, com a ajuda dos seus resultados. (...) Esta compulsão a orientar-se pelos próprios resultados, como se fossem caminhos e meios do método que progride, é a essência do caráter de exploração organizada da pesquisa. (GA 5: 84)

Anteriormente, Heidegger preocupara-se com o fato de que as asserções teóricas interconectadas obscureciam a descrição das ciências dos entes que elas desse modo descobriam. No ensaio "Imagem de mundo", uma tendência análoga torna-se o modus operandi definidor da pesquisa científica. Satisfazer as incessantes demandas do empreendimento de pesquisa por novos problemas para serem trabalhados, e novos recursos materiais, conceituais e institucionais para aplicar a esses problemas, torna-se mais importante do que a abertura e a descoberta dos entes: "O que ocorre de modo iminente com a difusão e consolidação do caráter institucional das ciências? Nada menos que o asseguramento da primazia do método diante do ente (natureza e história) que se torna, assim, objetivo, através da pesquisa.” (GA 5: 84). O caráter empreendedor da ciência moderna também transforma seus participantes. Pesquisadores não são intelectuais [scholars]. Suas virtudes características não são a erudição, mas a precisão; não a reflexão, mas a atividade constante; não o insight, mas a eficiência em realizar o trabalho.

No entanto, qual é o "trabalho" da ciência? Em Ser e Tempo, a ciência buscava descobrir os entes enquanto subsistentes. Os filósofos poderiam então guiar as interpretações científicas dos entes com insights da ontologia fundamental. Contudo, a orientação moderna da ciência enquanto pesquisa apresentada em "A época da imagem de mundo" mina qualquer governância filosófica. Ela busca maximizar a flexibilidade do próprio empreendimento de pesquisa, não-restringido pela consideração anterior de um domínio de entes: 
A vantagem que se exige deste sistema não consiste em uma relação qualquer de unidade entre as regiões de objetos - uma relação rígida e ficticiamente baseada em conteúdos - , mas na máxima agilidade, livre e ao mesmo tempo regrada, das permutações, interrupções e retomadas das pesquisas, de acordo com a tarefa que as comanda a cada momento. Quanto mais a ciência se especializa exclusivamente na operosidade e dominação do seu processo de trabalho, e mais realista e livre de ilusões é o deslocamento da exploração organizada em institutos e escolas de pesquisa, mais irretorquivelmente as ciências conquistam a consumação da sua essência moderna. (GA 5: 86)

O que faz a tarefa da pesquisa importante não é a significância intrínseca das descobertas projetadas, mas a possibilidade de abrir novas perspectivas para a pesquisa ulterior. Aqui, Heidegger enfatiza a afinidade entre a ciência moderna e a tecnologia, não simplesmente por causa das aplicações tecnológicas do conhecimento ou dos usos científicos da tecnologia. Mais do que isso, cada uma inexoravelmente ultrapassa qualquer consideração que possa restringir a expansão de suas capacidades para cálculo e controle. Não existe e não pode haver mais "em-função-de-que" para a pesquisa científica moderna; ela determina e calcula a fim de expandir o domínio de pesquisa, ao tornar os entes mais extensa e inteiramente calculáveis. A caracterização de Heidegger do empreendimento de pesquisa é, assim, reminiscente da visão de Platão da alma do tirano, conduzido por uma aspiração insaciável à mestria que não consegue reconhecer nenhum limite ou objetivo inerentes.

Existe uma importante dimensão prática e política nesta crítica da ciência moderna. Ao longo de sua carreira, Heidegger visou a governância filosófica das ciências (não apenas as ciências naturais, mas todas as disciplinas acadêmicas) nos termos da necessidade por uma reforma universitária (CROWELL, 1997). Sua descrição das ciências como ultrapassando qualquer consideração normativa mais ampla é, em parte, uma resposta a sua própria tentativa desastrosa cinco anos antes de dar um direcionamento filosófico à Universidade de Freiburg como reitor sob o regime nazista. De qualquer maneira que se avalie a relação entre a concepção de Heidegger e o programa político nazista, Heidegger rapidamente considerou a universidade completamente recalcitrante a seus objetivos filosóficos. 
O que a concepção revisada de Heidegger sobre a ciência moderna implica para a filosofia da ciência, afinal? Apesar de abandonar a ontologia fundamental e a concepção a-histórica de ciência enquanto descobridora de entes como subsistentes, Heidegger continuou a situar a ciência no centro de uma grande história filosófica sobre a verdade e o ser. A convergência da ciência e da tecnologia era concebida como um fenômeno essencial da modernidade e, assim, como um foco para a reflexão metafísica. A tecnociência permitiu aos próprios entes mostrarem-se como calculáveis e determináveis e, desse modo, revelou a perda iminente de quaisquer diferenças significativas no mundo moderno. A fonte dessa tendência não foi somente um movimento sociológico em direção à autonomia profissional das instituições científicas, mas uma transformação metafísica da inteligibilidade dos entes.

Esta reconcepção mudou a significância de concepções epistemológicas da ciência. Não mais meros erros filosóficos, elas supostamente expressam a "errância" do próprio mundo moderno, enquanto a "idade do mundo-imagem": "A imagem do mundo, entendida de modo essencial, não significa uma imagem do mundo, mas o mundo concebido enquanto imagem. O ente em sua totalidade agora é tomado de tal forma que ele só passa a ser na medida em que é posto por um homem que o representa e produz." (GA 5: 89). Heidegger não estava, desse modo, endossando uma tese idealista ou construtivista em relação aos entes. Em vez disso, ele estava afirmando que o ser dos entes (sua inteligibilidade, os modos em que podem se manifestar) é agora determinado pelas demandas do pensamento e da ação humanos, de maneira que também reconcebem os humanos como sujeitos. A ligação entre estas reconcepções torna-se aparente nos tratamentos da consideração dos entes enquanto "objetividade" ou representação correta. O ideal de objetividade é permitir que o objeto mostre-se como é, sem estar mudado por como o concebemos ou como lidamos com ele. Mas o que é desse modo determinado não é o objeto, mas nossas condutas com ele. Tomar a posição correta em direção a ele ou empregar os métodos corretos é considerado decisivo para a questão de se ele mostra-se corretamente. A representação e a práxis humanas, portanto, parecem arbitrar o que é real.

Essa concepção aparentemente exalta os seres humanos: nossas normas e objetivos governam a inteligibilidade de tudo e qualquer coisa. Mas Heidegger pensou que o sentido do domínio era ilusório. A objetificação dos entes e a subjetificação da nossa consideração a eles, inexoravelmente associadas, inevitavelmente transformam a própria descrição em um objeto adicional (um "valor") para o sujeito. Valores, então, precisam, por sua vez, de clarificação e avaliação objetiva, mas a sua objetificação enquanto valores a serem escolhidos mina a sua 
autoridade sobre a escolha. "O valor parece expressar que nos ocupamos com o que é mais valioso, ao tomarmos uma posição em relação a ele; contudo, o valor é o véu exaurido e esfarrapado que encobre a objetividade do ente já superficial e nivelada." (GA 5: 102). Essa perda na descrição para além de nós mesmos e, por isso, da possibilidade de que aquilo que fazemos poderia fazer uma diferença significativa, supostamente uniu a ciência e a tecnologia com a subjetivização da arte e do sagrado como os "fenômenos essenciais da modernidade".

Essa concepção historicizada da filosofia enquanto metafísica reteve a prévia avaliação negativa de Heidegger acerca da capacidade das ciências de compreender seu significado e normatividade próprios. A ciência como tal não poderia descobrir sua "essência", a metafísica do mundo enquanto imagem que realizou a transformação da ciência em um empreendimento de pesquisa parece apropriada e inevitável. Somente a reflexão filosófica poderia manter aberta a possibilidade de uma compreensão alternativa. No entanto, essa afirmação dependeu de uma distinção controversa entre ciência e filosofia. Em preleções contemporâneas a "A época da imagem de mundo", Heidegger reconheceu que Galileu e Newton, ou Heisenberg e Bohr, estavam fazendo filosofia, mais do que "mera" ciência". A necessidade por tal separação sugere dificuldades com a afirmação de Heidegger de que a ciência inevitavelmente impede uma compreensão ontológica mais fundamental: o trabalho científico mais importante e influente teria que contar como filosofia, precisamente porque era inquestionavelmente perspicaz.

Ao longo de sua carreira, Heidegger, assim, caracterizou a ciência de maneira análoga a sua associação anterior da ciência com o falatório. Ciência "como tal", para Heidegger, nunca foi a abertura de um descobrimento genuíno de como os próprios entes manifestam-se, mas somente um esforço irrefletido ("impensado") para garantir os entes no interior de um descobrimento primário previamente estabelecido. Essa atitude torna-se possível, contudo, por um erro mais fundamental. Ciência como tal não pode ser essencialmente "não-verdadeira" dessa maneira sem uma essência, em primeiro lugar, a não ser que haja algo como "ciência como tal". As essências heideggerianas são sempre ontológicas. Em Ser e Tempo, a essência da ciência era descobrir entes como subsistentes. Mais tarde, ele afirmou que a ciência moderna projetava entes como calculáveis e determináveis, em maneiras que governam qualquer conceitualização científica antecipadamente: “A física (...) nunca poderá renunciar

4 Heidegger (GA 41, p 67). Em Ser e Tempo, Heidegger citou a teoria da relatividade como um exemplar do redespertar ontológico na física (SZ: 9-10). A omissão do nome de Einstein ao lado de Heisenberg e Bohr dez anos depois inevitavelmente encoraja questões sobre a deferência de Heidegger a campanhas nazistas contra a "física judaica". 
a uma coisa: que a natureza anuncia-se a si mesma de alguma maneira calculadoramente constatável e que ela permanece determinável como um sistema de informações" (GA 7: 23 [MR - alterado a partir do original]). O que é ontologicamente crucial sobre essa maneira de revelar, para Heidegger, é sua ultrapassagem inexorável de quaisquer questões ou desafios para as quais a demanda de calculabilidade poderia ser responsabilizada. $\mathrm{O}$ ordenamento das ciências e o cálculo de entes somente expandem o domínio da pesquisa, tornando os entes mais completa e extensivamente calculáveis, sem mais "em-função-de".

A interpretação de Heidegger da ciência moderna enquanto expansão inexorável do controle calculativo pode parecer inicialmente plausível à luz da "Segunda Revolução Científica". Nos séculos XVIII e XIX, as ciências baconianas da química, calor, eletricidade, magnetismo, e mais tarde, biologia e geologia foram gradualmente envolvidas no interior de uma ciência experimental e matematizada. No século XX, seu alcance havia se expandido a fenômenos nunca tão pequenos, imensos ou distantes, e até mesmo a fenômenos complexos ou caóticos. O domínio da manipulação experimental e da modelagem teórica parece expandir-se sem limites aparentes. Contudo, a construção feita por Heidegger da expansão inexorável da ciência negligencia que somente poucos fenômenos nesses domínios têm relevância científica. A maioria das verdades sobre o mundo natural não tem qualquer significância científica; a pesquisa científica, em vez disso, foca sua atenção em fenômenos específicos, sistemas experimentais, e conceitos e modelos teóricos que parecem promover a compreensão científica. E como as próprias concepções de Heidegger sugerem, tal compreensão é sempre orientada em direção a um avanço subsequente, não a uma abordagem retrospectiva de conhecimento acumulado.

Além disso, quais fenômenos estão em questão em um dado campo ou programa de pesquisa tem frequentemente mudado com o tempo, acompanhado por mudanças sobre o que está em jogo. Por exemplo, Hans-Jörg Rheinberger (1997) observou várias ocasiões consecutivas quando os estudos experimentais do câncer mudaram de maneira relativamente suave para investigações dos processos celulares "normais" que se manifestam em células cancerosas. O que importava cientificamente não era mais a diferença entre células normais ou anormais, mas as características em comum de suas estruturas e funções. A "Revolução de Novembro" de 1973 na física, marcada pela descoberta de correntes neutras fracas, é outro exemplo, com mudanças fundamentais em quais eventos de alta-energia são merecedores de estudo (da dispersão suave de hádrons para as interações lépton-lépton e a dispersão dura de hádrons), e em direção a simetrias e a rupturas de simetrias na modelagem teórica como 
questões centrais na modelagem teórica (GALISON, 1987: capítulo 4; PICKERING, 1984). Tais casos não podem ser considerados apropriadamente como imposições de uma orientação predeterminada em direção ao controle calculativo sobre a natureza como um recurso flexível, porque o que importa para compreender calculativamente e o que está em jogo para seu sucesso, mudou. Tais mudanças, em vez disso, refletem uma abertura no interior da ciência em permitir que as próprias coisas mostrem-se inteligíveis de novas maneiras, e faz isso deixando que "os resultados reais guiem as decisões sobre o que fazer em seguida” (RHEINBERGER, 1995, p. 60).

Longe de buscar invariavelmente maior domínio, tais mudanças podem $s a-$ crificar a precisão calculativa e o controle laboratorial para desenvolver preocupações diferentes. A adaptação de Dobzhansky da genética de drosófilas para estudar a variação genética em populações naturais sacrificou deliberadamente tanto a precisão experimental quanto a tratabilidade matemática da sucessão (KOHLER, 1994, capítulo 8). De maneira similar, a atenção para os fenômenos fronteiriços semiclássicos da chamada "mecânica quântica pós-moderna" abandona a elegância matemática e a sistematicidade ao aproveitar-se simultaneamente dos vários modelos formalmente inconsistentes, para encorajar uma física de complexidade irredutível (HELLER e TOMSOVIC, 1993). Tal física da complexidade procura uma compreensão mais profunda de fenômenos "caóticos", que reconhece os limites da predição e do controle detalhados.

Frequentemente o que está em jogo em mudanças como essas é fundamental para a auto-compreensão humana. O trabalho de Dobzhansky ajudou a formar a síntese neo-darwinista, que não só posicionou a evolução pela seleção natural no centro de uma biologia mais unificada, mas que também teve consequências mais amplas, indo do eclipse biológico de "raça" a classificações de inteligência e cultura como adaptações evolutivas. A mecânica quântica pós-moderna rejeita o fundamentalismo quase teológico que governa muito da física de alta-energia recente, abandonando a busca por uma "Teoria de Tudo" unificada em favor de uma compreensão mais local e situada. De maneira similar, a emergência, como uma fênix, da biologia do desenvolvimento das cinzas da embriologia, e o concomitante eclipse da genética pela genômica, desafiam as concepções, agora familiares, de genes e DNA enquanto "segredo da vida" e sucedâneo biológico para a alma controláveis através de cálculo (KELLER, 1992; NELKIN e LINDEE, 1995; OYAMA et al., 2001).

Precisamos compreender que essas mudanças têm amplo alcance na significância científica (em que "compreensão" é entendida não cognitiva e restrita- 
mente, mas no sentido de Heidegger, de habilidade de responder apropriadamente a possibilidades). Mas a aspiração de Heidegger por uma história filosófica, grandiosa e nostálgica do ser obscurece esses e outros casos em que diferenças significativas emergem dos esforços científicos de retirar os fenômenos do ocultamento. A questão em se falar assim sobre a ciência, de maneira mais parecida com as observações de Heidegger sobre a arte, não é reverter a hierarquia de Heidegger, proclamando, ao invés disso, a ciência como um local privilegiado para o acontecimento da verdade. Mais do que isso, estou questionando quaisquer limites precisos ou mesmo significantes entre a ciência e outros comportamentos significativos enquanto práticas que permitem aos entes mostrarem-se a si mesmos de maneira inteligível. Meus exemplos foram escolhidos porque eles não podem ser corretamente descritos nem como determinações científicas de como as coisas importam para nós, nem como determinações socioculturais de significância científica. Em vez disso, eles mostram como a compreensão científica é parte integral de uma abertura de possibilidades histórica e mais ampla, no interior da qual as práticas científicas adquirem e transformam suas questões e desafios. $\mathrm{O}$ tratamento de Heidegger da orientação para o futuro da pesquisa científica enquanto mais básica do que a avaliação retrospectiva do conhecimento contribui construtivamente para compreender esse aspecto da ciência. Desenvolver essas contribuições mais amplamente exige, no entanto, abandonar o essencialismo residual de Heidegger sobre a ciência, e especialmente sua insistência de que a ciência pode desempenhar somente um papel derivativo, e mesmo contraprodutivo, em tornar inteligíveis nossa situação e seus desafios.

\section{Nota do autor:}

Partes deste capítulo são adaptadas de Rouse (2003). Uma versão preliminar foi apresentada para a International Society for Phenomenological Studies em 2002. Traduções de Sein und Zeit e Holzwege (GA 5) foram modificadas. Agradeço a William Blattner e Taylor Carman pelo exame crítico das traduções revisadas [aplicadas ao texto em inglês publicados no artigo original], e aos editores por comentários úteis a todo o artigo. 
BRANDOM, R. (2005) Heidegger's categories in Being and Time. In H. Dreyfus e M. Wrathall (eds.), Blackwell Companion to Heidegger. Oxford: Blackwell.

CROWELL, S. G. (1997) Philosophy as a vocation: Heidegger and university reform in the early inter-war years. History of Philosophy Quarterly, 14, 255-76.

DREYFUS, H. L. \& HALL, H. (1992) Heidegger: A Critical Reader. Oxford: Blackwell.

GALISON, P. L. (1987) How Experiments End. Chicago: Chicago University Press.

GUIGNON, C. B. (1993) Cambridge Companion to Heidegger. Cambridge: Cambridge University Press.

HAUGELAND, J. (1998) Having Thought: Essays in the Metaphysics of Mind. Cambridge, MA: Harvard University Press.

(2000) Truth and finitude: Heidegger's transcendental existentialism. In M. Wrathall \& J. Malpas (eds), Heidegger, Authenticity and Modernity. Cambridge, MA: MIT Press.

HEIDEGGER, M. (1967) What Is a Thing? (trad. por W. Barton \& V. Deutsch). Chicago: Regnery (originalmente publicado em 1962).

HELLER, E. \& TOMSOVIC, S. (1993) Postmodern quantum mechanics. Physics Today, 46, 38-46.

KELLER, E. F. (1992) Secrets of Life, Secrets of Death: Essays on Language, Gender and Science. New York: Routledge.

KOHLER, R. E. (1994) Lords of the Fly: Drosophila Genetics and the Experimental Life. Chicago: Chicago University Press.
KUHN, T. S. (1970) The Structure of Scientific Revolutions. Chicago: Chicago University Press.

MCDOWELL, J. H. (1994) Mind and World. Cambridge, MA: Harvard University Press.

PICKERING, A. (1984) Constructing Quarks: A Sociological History of Particle Physics. Chicago: Chicago University Press.

NELKIN, D. \& LINDEE, S. (1995) The DNA Mystique: The Gene as a Cultural Icon. San Francisco:W.H. Freeman.

OYAMA, S., GRIFFITHS, P. E. \& GRAY, R. D. (2001) Cycles of Contingency: Developmental Systems and Evolution. Cambridge, MA: MIT Press.

RHEINBERGER, H.-J. (1995) From microsome to ribosomes: "strategies" of "representation." Journal of the History of Biology, 48, 49-89.

RHEINBERGER, H.-J. (1997) Toward a History of Epistemic Things: Synthesizing Proteins in the Test Tube. Stanford, CA: Stanford University Press.

ROUSE, J. T. (2002) How Scientific Practices Matter: Reclaiming Philosophical Naturalism. Chicago: Chicago University Press. (2003) Heidegger on science and naturalism. In G. Gutting (ed.), Continental Philosophies of Science. Oxford: Blackwell.

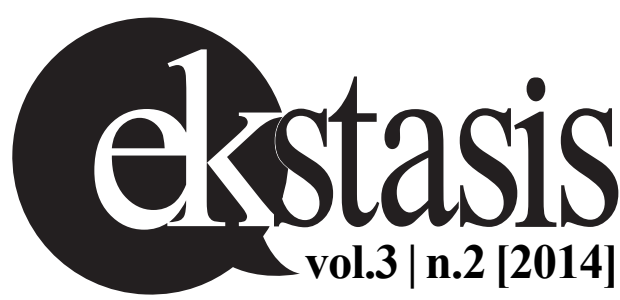

